\title{
Translation in College English Teaching from the Prospect of Intercultural Communication
}

\author{
Ying Zhao \\ School of Foreign Languages \\ Huanghe Science and Technology College \\ Zhengzhou, China
}

\begin{abstract}
It is an inevitable trend in the development of College English translation teaching to penetrate the cultural awareness and cultivate the students' ability of English translation. In recent years, always international exchanges and cooperation, further strengthen, our country college English translation teaching pay more attention to the to the penetration of the cultural elements and cultural elements of the present, and based on fast culture from the perspective of English sentence, paragraph, or literature translation can reflect English translation of the era, practical and the humanities. In this paper, from the analysis of the relationship between the English translation and culture, and expounds the present situation of current college English translation teaching. Finally, it puts forward from a cross cultural perspective, to carry out effective strategies of College English translation teaching and to readers.
\end{abstract}

Keywords-cross cultural perspective; college English; translation teaching; current situation; effective strategy

\section{INTRODUCTION}

Language is the inevitable result of cultural generation and development, and culture is widely spread and carried forward by language. From this perspective, culture and language are closely related. English translation is a kind of important form of the English language; it is inevitable have the relationship with culture, just like a narrow strip of water, whether the middle and senior high school English education, or higher vocational English teaching and college English teaching, all cannot dissever the relationship between language and culture. In terms of college English translation teaching, it is imperative to teach cultural elements and cross-cultural context during college English translation.

To some extent, the English translation is a kind of important form of cross-cultural communication. In this process, the translators should not only realize conversion between languages, but also to ensure the conversion and communication between different cultural forms and cultural patterns. Relying on culture as the basis for college English translation, we can better cater to the development of the times, serve the economic development of the society and promote the development and progress of the world. In view of this, during the translation teaching, college English teachers must correctly deal with the relationship between the English translation and culture, achieve the purpose that culture lead translation, promote translation, and enrich the connotation of the translation.

\section{A BRIEF ANALYSIS OF THE PRESENT SituATION OF COLLEGE ENGLISH TRANSLATION TEACHING}

\section{A. The Present Situation of College English Translation Teaching}

The rapid development of economic globalization makes the social all walks of life showing a booming trend, and the need of translation talented person's demand is also growing in every field, and the university as the important bases of cultivating outstanding talents of the English translation to the nation, also shoulders the burden of more serious English translation talents cultivation. Of course, the progress of the time and the development of the society have rapidly promoted the development of English translation teaching in universities. The English translation teaching also presents a flourishing scene. For example, in recent years, the excellent intercultural English translation talents cultivated by universities have made great contributions to international exchanges and cooperation. This shows the comprehensive ability of English translation talents, they will no longer stiffly in English words translated into Chinese characters, but added more cultural element, highlight the more intense human nature color, with more era characteristics. Of course, more teachers pay attention to the penetration of crosscultural translation in English translation teaching, but there are some other teachers didn't recognize the relationship between translation and culture, in their teaching process, they blindly follow others every step. Translation teaching is still in a low stage. Therefore, the college English teachers should be good at reflecting, evaluating and summarizing the teaching situation, so as to break the predicament of translation teaching and improve the effect of translation teaching.

\section{B. The Problems of College English Translation Teaching}

The cross-cultural factors in college English translation teaching advocates the penetration at the same time, translation teaching indeed has obtained certain achievements, but at the same time, we still need to be aware of the university English cross-cultural problems in English 
teaching, these problems more or less affect the intercultural translation teaching of English teaching effect.

College English teaching due to neglect of translation ability leads to the generally low status of students' ability to translate. With China' $\mathrm{s}$ foreign exchanges become more frequent, and the degree of internationalization of the continuous improvement of modern society, the demand for foreign language professionals have become increasingly prominent, putting forward higher requirements for foreign language communication skills, which requires the application ability of our students in foreign language communication need to greatly improve. Translation ability is an important manifestation of the capacity of the communication application. However, for a long time, translation teaching in English teaching has not been able to get enough attention. Classroom activities, teachers do not pay attention to students of translation skills, leading to poor students' ability. The teachers and students are not given enough attention to the translation, and the teachers did not give students a more systematic introduction to translate common sense and skills. Students cannot spare the amount of translation practice in English test as in CET4 or CET 6, for various reasons lead to students' ability to translate are always at a disadvantage. And limited English class, alone, sets up translation training course. Many teachers only emphasize on listening, speaking, reading and writing, rarely attend to the cultivation of students' ability to translate. Even take into account the translation, the English and Chinese language conversion, results in students for" westernized" translation, and even does not comply with the Chinese language habit or a literary accumulation of Chinese characters. It results that many students go to work, not competent in English skills, even to translate simple business letter. In English teaching, too much emphasis on the allEnglish teaching, such teaching methods to some extent, to the students to create learning English language environment, training students' listening and speaking ability. However, it almost abandons the mother tongue, and do not attach importance to the translation teaching, so that students not only English skills are not in place, and the mother tongue were also affected, causing students to translation barrier or confusion. The translation process involves understanding and expression of the two languages systems.

\section{AN EFFECTIVE STRATEGY FOR COLLEGE ENGLISH TRANSLATION TEACHING BASED ON CROSS-CULTURAL PERSPECTIVE.}

\section{A. In the Daily Translation Teaching to Carry on the Cultural Knowledge Infiltration}

Cross-cultural translation teaching are needed for English teachers to the implement the cultural knowledge step by step, subtly influence students, to improve the recognition of intercultural translation, then truly improve their ability of cross-cultural English translation. First, teachers can fully tap the Anglo-American culture in college English textbooks. As is known to all, various versions of college English textbooks contain rich knowledge of British and American literature, and teachers should make full use of this cultural content to improve teaching quality. Second, enrich the process of translation teaching and skillfully penetrate it in the translation process. Teachers can use multimedia video and audio to infiltrate British and American culture in the course of teaching, so as to expose students to more and more comprehensive knowledge of English culture. Third, teacher need to recommend the classic British and American extracurricular reading literature for the students.

\section{B. It is Necessary to Cultivate Students' Consciousness of Cross-cultural Translation Consciously}

The cultivation of students' awareness and ability of cross-cultural translation is an important and basic way to promote the success of college English intercultural translation teaching. Specifically, teachers should make the following points:

- Raise students' awareness of cultural equality. Many students are biased against the cultural differences between China and the west, and they can't deal with the differences between Chinese and English correctly. They always avoid the British and American culture consciously or unconsciously, which is not conducive to the development of crosscultural English translation teaching. Therefore, the teacher should let the students establish the concept of cultural equality, do well education and guide work.

- Make students contact and understand cross-cultural knowledge. In English translation, in order to make students correctly accurately, refined presented to express the origin. In addition, teachers should make a conscious effort to correct students' cultural and rational mistakes in translation and guide them to become excellent English translators.

The translation is a cross-cultural communication activity. Rapid transport and communication tools, the accelerating pace of global economic integration, with the increasingly frequent exchanges between different countries and nations, the increasing urgency of cultural dialogue, and the people of the "global village" has gained more focus of attention. In this case, the importance of translation as a cultural exchange pathway has become increasingly acute. The sensitivity of the differences between the different cultures is crosscultural awareness or being called "cultural sensitivity" .From a psychological perspective, cross-cultural communication ability is built on the basis of cross-cultural awareness training. Similarly, cross-cultural communication translation, as the participants of the first round of communicative activities, the translator cross-cultural awareness is the key to its success Intercultural Communication and Translation. For cross-cultural awareness, more agreeable to the concept of the currently only article on the study of cross-cultural awareness is the American scholar Harvey's (Harvey, 1979) point of view. He believes that cross-cultural awareness is sensitivity awareness of the participants in the cross-cultural communication and cultural factors, and usually divided into four levels. Mean respectively: 
- Those who have been recognized as a weird surface cultural phenomenon of cognitive.

- In contrast to those with native language culture but is considered to be incredible and the lack of significant cultural features of the concept of cognitive.

- To obtain rational analysis of the cultural characteristics of the cognitive.

- From the perspective of different cultures holders aware of different cultures.

The fourth level is the highest state of cross-cultural awareness, participants were asked to have "empathy" and "cultural integration" into the ability. Fully understand the differences of different cultures on the basis of their own "substituting" each other' s state of mind, put ourselves in body odor encounters and feelings of others, observation and reflection on different cultural backgrounds. In Harvey philosophy, the focus is the awareness of the different cultures, of course, the premise of default has a full understanding of the national culture. For a face of two cultures translator, choosing how to deal with cultural factors, should be aware of why they want to do it that way. In addition to the above, the cross-cultural awareness should also have its own unique meaning. The translator crosscultural awareness can be summarized as the following three points:

- Of primitive cultural awareness;

- Awareness of the culture of the target language;

- The ability to explain own translation strategies and methods.

\section{CONCLUSION}

To sum up, in the teaching process of college English translation, the intercultural consciousness is permeated, and the continuous improvement of intercultural translation teaching strategies has two-way promotion significance for teachers' "teaching" and "learning" of students. Crosscultural communication is an important skill for the students in college English learning and English teachers should improve the teaching methods, gradually improve the students' ability of intercultural communication .In terms of college English translation teaching, teachers should first handle the relationship between the English translation and culture, and then analysis the current problems in crosscultural translation teaching, and based on this targeted to explore effective cross-cultural translation teaching strategy. Only in this way, can improve the students' English translation ability, it will make them better serve the country and serve the society.

\section{REFERENCES}

[1] Hanvey,R.G.ReadinginCrossCulturalCommunication[M]. NewburgHouse, 1979.

[2] Peter Newmark, About Translation [M]. Multilingual Matters, 1991.
[3] Susan Bassnett, Translation studies, "Translatio, History and Culture" [M].Cassell, 1995.

[4] Zhang Ruie, "Construction of the Subjects' Communication System in Translation Teaching for English Majors" [D], Shanghai International Studies University, 2012 (05).

[5] Zhang Xia, "Research about Countermeasures to Improve the Efficiency of College English Translation Teaching” [J].Overseas English, 2010(09).

[6] Xu Jun, "A Corpus-based Study on the Current Status of the English Textbooks of Translation and the Teaching of Translation"[J], Computer-assisted Foreign Language Education, 2008(09).

[7] Jiang Xiaoli, "On Translation Teaching in College English from an Empirical perspective" [J],

[8] Xuan Yimei, "Discussion about College English Translation Teaching" [J], Fujian Tribune (A Economics \& Sociology Monthly), 2009(08).

[9] Deng Yan, Liu Lianfang, "Research about the Integrated Innovation of English Translation Teaching mode" [J], Journal of Hunan Agricultural University (Social Science. Quality-oriented education research), 2008( 09) (10) Li Li, "Research about the New Teaching Mode of Translation-"Imitate" the Practical Application of Translation Teaching Mode" [J], Kao Shi Zhou Kan , 2013(08). 